\title{
Factors affecting conjugative transfer of plasmid pWG613, determining gentamicin resistance, in Staphylococcus aureus
}

\author{
S. B. AL-MASAUDI, A. D. RUSSELL* and M. J. DAY \\ School of Pure and Applied Biology and "Welsh School of Pharmacy, University of Wales College of Cardiff, PO Box \\ 951, Cardiff
}

\begin{abstract}
Summary. Factors that are known to influence plasmid transfer in bacterial populations were studied for the conjugative plasmid pWG613, which determined gentamicin resistance in Staphylococcus aureus. The transfer frequency was largely unaffected over a wide range of temperature $\left(18-42^{\circ} \mathrm{C}\right) ; \mathrm{pH}$ also had little effect on the transfer frequency in the range $5 \cdot 0$ 8.5. High cell density and log phase cultures were required for optimal plasmid transfer, as were donor: recipient ratios of 0.003-3.3.
\end{abstract}

\section{Introduction}

Soon after the introduction of antibiotics into clinical practice, it became clear that Staphylococcus aureus could develop resistance to many agents. ${ }^{1-3}$ Antibiotic resistance in this organism is often plasmidencoded and may be transferred in the laboratory by transformation, transduction or conjugation. ${ }^{4-6}$ Plasmid transfer by phage-mediated conjugation (which requires the presence of phage in either donor or recipient without death of the former or lysis of the latter) occurs at a high frequency $\left(10^{-1}\right.$ per recipient) in mixed cultures and might also take place under natural conditions. ${ }^{7,8}$ In the last few years conjugative transfer of plasmids determining aminoglycoside resistance has been demonstrated between $S$. epidermidis and $S$. aureus. ${ }^{6-12}$ This finding could be of clinical significance and may explain the increased incidence of gentamicin resistance in staphylococci. $^{13-17}$

Various factors influence conjugative plasmid transfer amongst bacteria. These include temperature, $\mathrm{pH}$, cell density and the donor:recipient cell ratio. ${ }^{18-24}$ Very few reports have considered the effects of these factors in staphylococci. The aim of this work was to study their influence on the conjugative transfer of an aminoglycoside resistance plasmid to evaluate the potential for self-transmissible plasmid exchange among staphylococci.

\section{Materials and methods}

\section{Bacterial strains and growth conditions}

The bacterial strains used in this study are listed in the table. All were maintained on Nutrient Agar (Oxoid CM3) containing appropriate selective agents. Liquid cultures were grown in $10-\mathrm{ml}$ volumes of Nutrient Broth (NB; Oxoid CM1). Nutrient Agar (NA; Oxoid), Brain Heart Infusion Agar (BHIA: Oxoid CM375), Diagnostic Sensitivity Test Agar (DSTA: Oxoid CM261) and Blood Agar (BA) were

Table. Source and properties of $S$. aureus strains and mutants

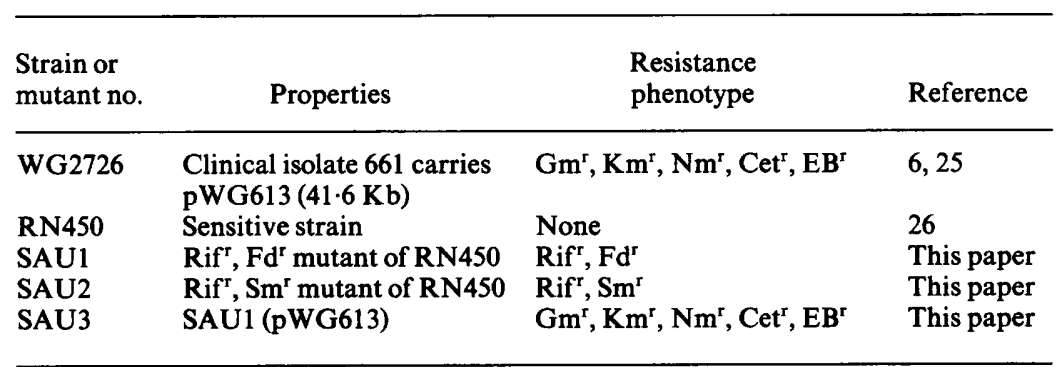

Cet, cetrimide; EB, ethidium bromide; Fd, fucidic acid; Gm, gentamicin; Km, kanamycin; Nm, neomycin; Rif, rifampicin; Sm, streptomycin. 
used as culture media. Blood Agar comprised Columbia Blood Agar (Oxoid) plus horse blood 5\%.

\section{Mating procedure}

The $S$. aureus donor SAU3 and recipient SAU2 strains were grown separately overnight in NB, then diluted 10-fold into pre-warmed fresh medium and incubated for $4 \mathrm{~h}$ at $37^{\circ} \mathrm{C}$. Equal $(0.25-\mathrm{ml})$ volumes of these cultures were mixed in $2.5 \mathrm{ml}$ of fresh NB and filtered through cellulose acetate membrane filters $(0.45 \mu \mathrm{m}$ pore size, $25 \mathrm{~mm}$ diameter; Oxoid). The filters were incubated, face up, on the surface of NA for $15 \mathrm{~h}$ at $37^{\circ} \mathrm{C}$. The cells on the filters were then resuspended by vortex mixing for $2 \mathrm{~min}$ in $1 \mathrm{ml}$ of NB. Serial dilutions of the washings were plated on the appropriate selective media and incubated at $37^{\circ} \mathrm{C}$ for $48 \mathrm{~h}$. These media were NA containing gentamicin $5 \mathrm{mg} / \mathrm{L}$, streptomycin $60 \mathrm{mg} / \mathrm{L}$ or both these antibiotics. In some experiments cetrimide $(5 \mathrm{mg} / \mathrm{L})$ replaced gentamicin. Separate cultures of the donor and recipient strains were treated identically and in parallel as controls.

Colonies growing on the NA containing both antibiotics were classed as presumptive transconjugants and were counted after incubation for $48 \mathrm{~h}$. The transfer frequency was calculated relative to the counts of recipient cells present at the start of mating. Transconjugants were purified on media containing gentamicin plus streptomycin and replicated on to media containing other antimicrobial agents to test for co-acquisition of unselected markers.

\section{Factors affecting the transfer frequency}

The standard mating procedure was used. The effects on the transfer frequency of the incubation temperature prior to mating, and during mating; $\mathrm{pH}$; mating duration; cell density; the donor:recipient ratio and different media were investigated.

\section{Statistical analyses}

All transfer frequencies were the means of at least three determinations. Minimum significant ranges (MSR) were calculated by Tukey's honestly significant difference method. ${ }^{27}$ All differences were considered significant if $\mathrm{p}<0.05$.

\section{Results}

\section{Effects of different media on plasmid transfer}

Matings were performed on NA, BHIA, DSTA and BA. There was no significant difference in the transfer frequencies on any of the first three media $\left(1.6 \times 10^{-1}\right.$ to $7 \cdot 3 \times 10^{-2}$ per recipient), but the frequency on BA was significantly $(\mathrm{p}<0.05)$ lower $\left(5.4 \times 10^{-3}\right.$ per recipient).

\section{Effects of the mating period on plasmid transfer}

Transfer of the plasmid was first detected after $1 \mathrm{~h}$ and reached a maximum frequency after $6 \mathrm{~h}$ (fig. 1). Increasing the mating period to $24 \mathrm{~h}$ gave no further significant increase in the transfer frequency.

\section{Effects of temperature on plasmid transfer}

The influence of temperature on the transfer of pWG613 was investigated in two ways. Firstly the effect of the growth temperature before mating was examined. Individual donor and recipient cultures were grown separately for $4 \mathrm{~h}$ at various temperatures from 12 to $42^{\circ} \mathrm{C}$. Donor and recipient cultures grown at the same temperature were then mixed and

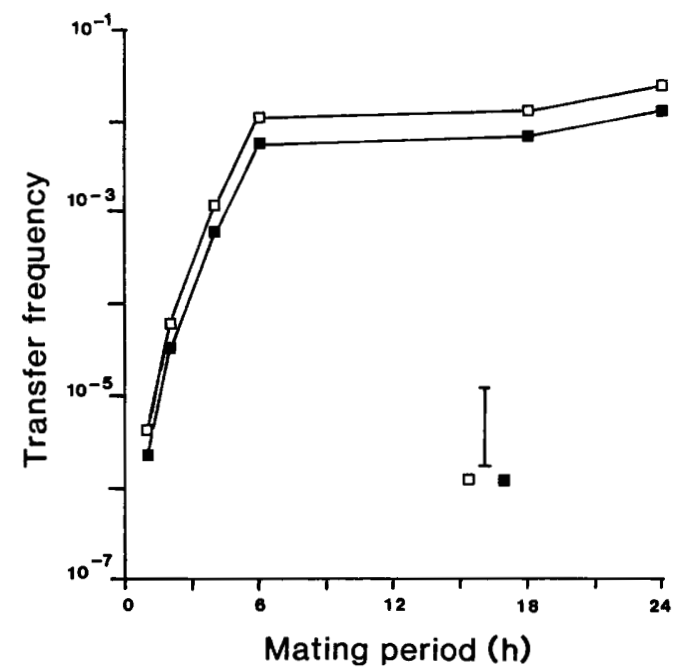

Fig. 1. The effect of the duration of mating period on transfer of plasmid pWG613. Transfer frequencies per recipient cell $(\square-\square)$ and per donor cell ( $\square-\square)$ present at the start of mating are shown. The bar represents the minimum significant range (MSR).

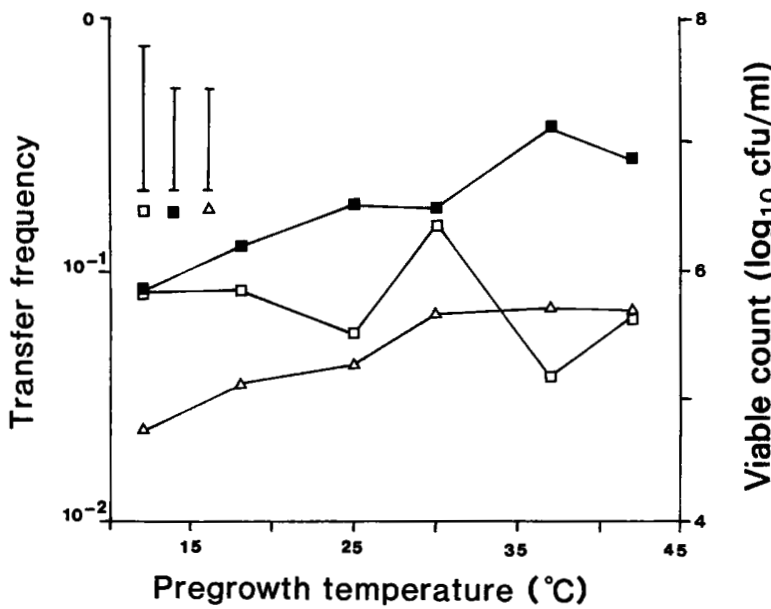

Fig. 2. The effect of growth temperature prior to mating on transfer of plasmid pWG613. The results are expressed per recipient cell present at the start of mating $(\square-\square)$. The numbers of recipient cells initially present ( $-\square)$ and transconjugants obtained $(\triangle-\triangle)$ are also shown. The bar represents the minimum significant range (MSR). 
harvested by filtration. The filters were incubated at $37^{\circ} \mathrm{C}$ for $15 \mathrm{~h}$. There was no significant temperaturedependent difference in the transfer frequency. Transfer frequencies were between $1.5 \times 10^{-1}$ and $4.0 \times 10^{-2}$ per recipient (fig. 2).

In other experiments, the donor and recipient cells were grown separately at $37^{\circ} \mathrm{C}$ for $4 \mathrm{~h}$, mixed and harvested on membrane filters. Individual filters were then incubated at temperatures between 10 and $42^{\circ} \mathrm{C}$. There was no difference in the maximal transfer frequency observed between 25 and $42^{\circ} \mathrm{C}$ (fig. 3). Transfer of the plasmid was significantly reduced, but remained detectable at $18^{\circ} \mathrm{C}$ but not at $10^{\circ} \mathrm{C}$.

\section{Effect of $\mathrm{pH}$ on plasmid transfer}

Transfer of pWG613 was not affected by $\mathrm{pH}$ values between 5.0 and 8.5 at 25 or $37^{\circ} \mathrm{C}$. Fig. 4 shows the

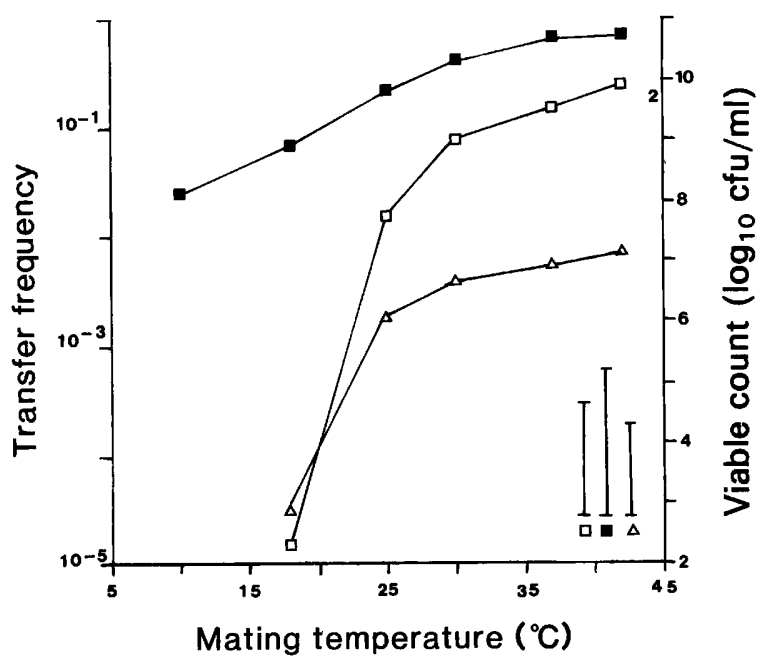

Fig. 3. The effect of mating temperature on transfer of plasmid pWG613. Results are expressed per recipient cell present at the start of mating $(\square-\square)$. The transconjugant $(\triangle-\triangle)$ and total recipient counts ( $\square$ ) at the end of mating are also shown. The bar represents the minimum significant range (MSR).

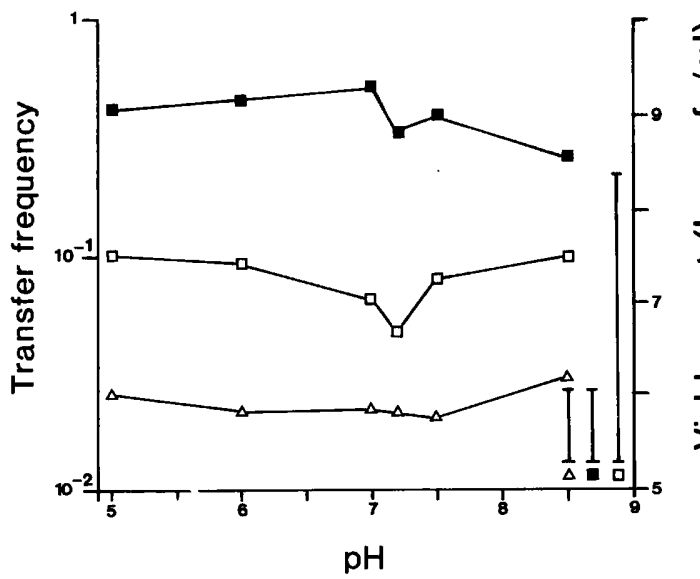

Fig. 4. The effect of pH on transfer frequency of plasmid pWG613. Results are expressed per recipient cell $(\square-\square)$ present at the start of mating. Transconjugant $(\triangle-\triangle)$ and recipient counts (ㄷ) at the end of mating are also shown. The bar represents the minimum significant range (MSR). transfer frequencies recorded at $37^{\circ} \mathrm{C}$; similar data were obtained at $25^{\circ} \mathrm{C}$.

\section{Effect of culture density on plasmid transfer}

The influence of the culture density on the transfer frequency was calculated. Maximum frequencies were obtained when the initial total (donor plus recipient) cell density was $1.8 \times 10^{7} \mathrm{cfu} / \mathrm{ml}$. The lowest initial density at which transfer was detected was $1.0 \times$ $10^{4} \mathrm{cfu} / \mathrm{ml}$. At initial densities of $1.8 \times 10^{2} \mathrm{cfu} / \mathrm{ml}$ no transfers were detected although the cell density had increased to $2.3 \times 10^{9} \mathrm{cfu} / \mathrm{ml}$ after $15 \mathrm{~h}$ (fig. 5). At high initial cell densities $\left(1.0 \times 10^{9} \mathrm{cfu} / \mathrm{ml}\right)$ the transfer frequency was reduced (fig. 5). Cell densities at the end of the 15 -h mating period were $\left(2.0 \times 10^{9}\right)-(2.0 \times$ $\left.10^{10}\right) \mathrm{cfu} / \mathrm{ml}$ and were not significantly dependent $(\mathrm{p}>$ 0.05 ) on the cell density at the start of mating.

\section{Effect of the donor : recipient cell ratio on plasmid transfer}

Transfer of the gentamicin resistance plasmid occurred at all the donor: recipient ratios used. Fig. 6 clearly shows that the maximum transfer frequencies were obtained over a wide range of initial donor: recipient cell ratios.

\section{Effect of selective markers on plasmid transfer}

Transcipients were selected on agar containing gentamicin or cetrimide together with streptomycin. The transfer frequency did not vary significantly according to the selective agent used $(p<0.05)$.

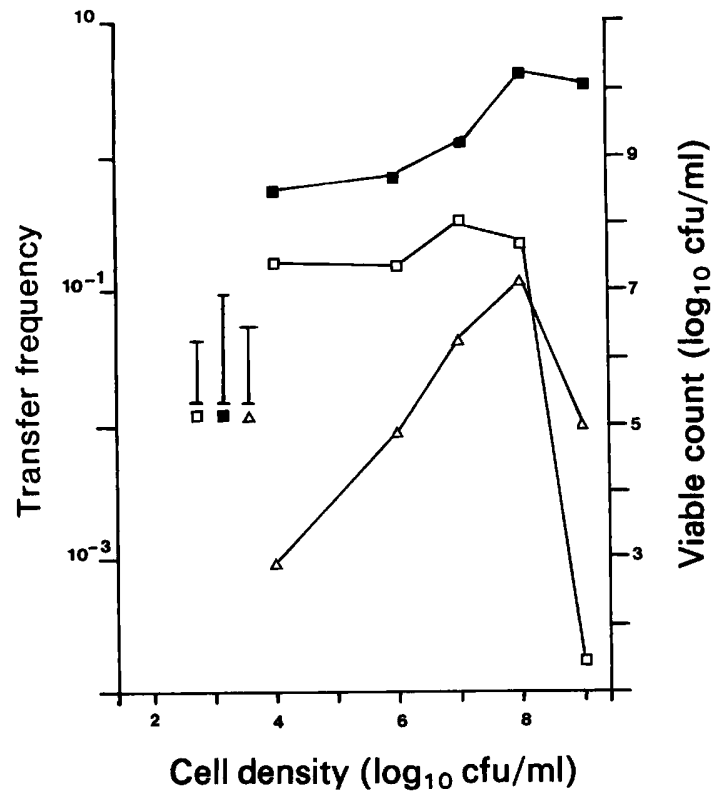

Fig. 5. The effect of cell density on the transfer frequency of plasmid pWG613. Results are expressed per recipient cell present at the start of mating $(\square-\square)$. Transconjugant $(\triangle-\triangle)$ and recipient counts (- The bar represents the minimum significant range (MSR). 


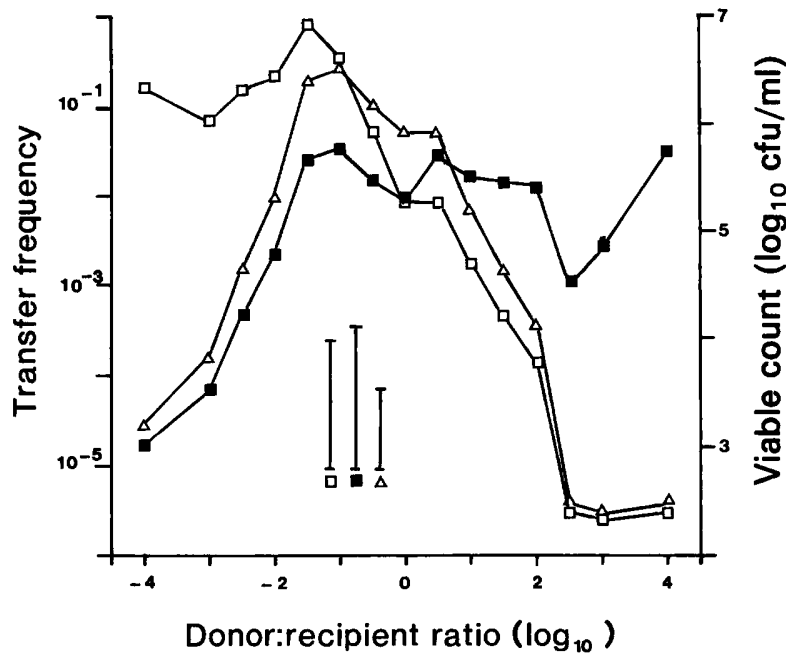

Fig. 6. The effect of the donor: recipient ratio on transfer frequency of plasmid pWG613. The transfer frequency is expressed per recipient ( $\square$ ) and per donor $(\square-\square)$ present at the start of mating. The total transconjugant count $(\triangle \triangle \triangle)$ is also shown. The bar represents the minimum significant range (MSR).

Transcipients invariably acquired resistance to both gentamicin and centrimide.

\section{Discussion}

Factors that might modify the transfer efficiency of the conjugative $S$. aureus plasmid pWG613 were examined. Similar transfer frequencies were obtained on NA, BHA, or DSTA but a decreased transfer frequency was noted on BA, probably caused by serum components which affect staphylococcal aggregation. This effect could be significant in vivo.

Transfer of plasmid pWG613 occurred within 60 min on filter membranes (fig. 2) and was maximal within $6 \mathrm{~h}$. The relationship between the total number of transconjugants and time (data not shown) indicated that the transfer frequency peaked at the eighth generation. The temperature of incubation before mating was not important in determining the frequency of plasmid transfer. Similarly, the mating temperature was not important in determining the rate of plasmid transfer over the range $25-42^{\circ} \mathrm{C}$. The transfer frequency was reduced at low temperature $\left(18^{\circ} \mathrm{C}\right)$ but remained high in absolute terms $(1.5 \times$ $10^{-5}$ per recipient). Transfer between staphylococcal populations could therefore take place at room temperature. The spread of plasmids determining aminoglycoside resistance in some hospitals might be explained by their ability to transfer amongst strains both in patients and in the environment.

The influence of $\mathrm{pH}$ was investigated at 25 and $37^{\circ} \mathrm{C}$. It has been reported elsewhere that $\mathrm{pH}$ and temperature can co-determine the plasmid transfer frequency. ${ }^{23}$ However, transfer of pWG613 remained similarly efficient at $\mathrm{pH}$ values from 5.0 to 8.5 . Curtiss $^{28}$ has also reported that drug resistance plasmids in Escherichia coli were transferred optimally over the same $\mathrm{pH}$ range.

In conjugation experiments, initial cell densities of $10^{4}-10^{8} \mathrm{cfu} / \mathrm{ml}$ were required to achieve high rates of plasmid transfer. At a higher or lower cell density the transfer frequency was depressed. The optimum transfer of plasmid pWG613 occurred at donor : recipient cell ratios between 0.003 and 0.3 (fig. 6).

This flexibility may help to account for the rapid "evolution" of gentamicin-resistant $S$. aureus strains through plasmid transfer in hospitals. A better understanding of this transfer process will help determine strategies for reducing the spread of resistance.

We gratefully acknowledge support from the Department of Biology, King Abdulaziz University and the Ministry of Higher Education, Saudi Arabia.

\section{References}

1. Shanson DC. Antibiotic-resistant Staphylococcus aureus. J Hosp Infect 1981;2: 11-36.

2. Brunton J. Antibiotic resistance plasmids of streptococci, staphylococci and bacteroides. In : Bryan LE (ed) Antimicrobial drug resistance. Orlando, FA, Academic Press Inc. 1984: 529-565.

3. Lyon BR, Skurray R. Antimicrobial resistance of Staphylococcus aureus: genetic basis. Microbiol Rev 1987; 51 : 88-134.

4. Lindberg M, Novick RP. Plasmid-specific transformation in Staphylococcus aureus. J Bacteriol 1973; 115: 139-145.

5. Lacey RW. Antibiotic resistance plasmids of Staphylococcus aureus and their clinical importance. Bacteriol Rev 1975; 39: 1-32.

6. Archer GL, Johnston JL. Self-transmissible plasmids in staphylococci that encode resistance to aminoglycosides. Antimicrob Agents Chemother 1983; 24: 70-77.

7. Lacey RW. Evidence for two mechanisms of plasmid transfer in mixed cultures of Staphylococcus aureus. J Gen Microbiol $1980 ; 119$ : 423-435.

8. Lacey RW. Antibiotic resistance in Staphylococcus aureus and streptococci. Br Med Bull 1984; 40: 77-83.

9. Forbes BA, Schaberg DR. Transfer of resistance plasmids from Staphylococcus epidermidis to Staphylococcus aureus: evidence for conjugative exchange of resistance. $J$ Bacteriol $1983 ; 153: 627-634$.

10. Goering RV, Ruff EA. Comparative analysis of conjugative plasmids mediating gentamicin resistance in Staphylococcus aureus. Antimicrob Agents Chemother 1983; 24: 450452.

11. McDonnell RW, Sweeney HM, Cohen S. Conjugational transfer of gentamicin resistance plasmids intra- and interspecifically in Staphylococcus aureus and Staphylococcus epidermidis. Antimicrob Agents Chemother 1983; 23: 151-160.

12. Schaberg DR, Power G, Betzold J, Forbes BA. Conjugative R plasmids in antimicrobial resistance of Staphylococcus aureus causing nosocomial infections. J Infect Dis 1985; 152: 43-49.

13. Vogel L, Nathan C, Sweeney HM, Kabins SA, Cohen S. Infections due to gentamicin-resistant Staphylococcus aureus strains in nursery for neonatal infants. Antimicrob Agents Chemother 1978; $13: 466-472$.

14. King K, Brady L, Thomson M, Harkness JL. Antibioticresistant staphylococci in a teaching hospital. Med J Aust $1982 ; 2: 461-465$.

15. Weinstein RA, Kabins SA, Nathan C, Sweeney HM, Jaff HW, Cohen S. Gentamicin-resistant staphylococci as hospital flora: epidemiology and resistance plasmids. $J$ Infect $D$ is $1982 ; 145$ : 374-382.

16. Dowd G, Cafferkey M, Dougan G. Gentamicin and methicillin resistant Staphylococcus aureus in Dublin hospitals : molecular studies. J Med Microbiol 1983; 16: 129-138. 
17. Carroll JD, Pomeroy HM, Russell RJ et al. A new methicillinand gentamicin-resistant Staphylococcus aureus in Dublin: molecular genetic analysis. J Med Microbiol 1989; 28: 1523.

18. George BA, Fagerberg DJ, Sanem JA. Antimicrobial resistance transfer in transport media. Appl Environ Microbiol 1981; 42: $548-549$.

19. Singleton $P$, Anson AE. Conjugal transfer of R-plasmid R1drd19 in Escherichia coli below $22^{\circ} \mathrm{C}$. Appl Environ Microbiol $1981 ;$ 42: 789-791.

20. Singleton $\mathrm{P}$, Anson AE. Effect of $\mathrm{pH}$ on conjugal transfer at low temperatures. Appl Environ Microbiol 1983; 46: 291292.

21. Altherr $\bar{M} \bar{R}$, Kasweck KL. In-situ studies with membrane diffusion chambers of antibiotic resistance transfer in Escherichia coli. Appl Environ Microbiol 1982; 44: 838-843.

22. Freter $\mathbf{R}$. Factors affecting conjugal plasmid transfer in natural bacterial communities. In: Klug MJ, Reddy CA (eds) Current perspectives in microbial ecology. 3rd International symposium on microbial ecology. American Society for Microbiology. Washington, D.C. 1984: p 105.
23. Rochelle PA, Fry JC, Day MJ. Factors affecting conjugal transfer of plasmids encoding mercury resistance from pure cultures and mixed natural suspensions of epilithic bacteria. J Gen Microbiol 1989; 135 : 409-424.

24. Reanney DC, Roberts WP, Kelly WJ. Genetic interactions among microbial communities. In: Bull AT, Slater JH (eds) Microbial interactions and communities. London, Academic Press. 1982: 287-322.

25. Emslie KR, Townsend DE, Bolton S, Grubb WB. Two distinct resistance determinants to nucleic acid-binding compounds in Staphylococcus aureus. FEMS Microbiol Lett 1985; 27: 61-64.

26. Townsend DE, Bolton S, Ashdown N, Grubb WB. Transfer of plasmid-borne aminoglycoside-resistance determinants in staphylococci. J Med Microbiol 1985; 20 : 169-185.

27. Sokal RR, Rohlf FJ. Biometry, 2nd edn. San Francisco, Freeman. 1981.

28. Curtiss R. Bacterial conjugation. Ann Rev Microbiol 1969; 23: 69-136. 